\title{
1 Food for thought: Eating before saliva collection and interference with SARS-CoV-2 detection
}

3 Matthew M. Hernandez ${ }^{1, \#}$, Mariawy Riollano-Cruz ${ }^{2}$, Mary C. Boyle ${ }^{2}$, Radhika Banu ${ }^{1}$, Paras Shrestha ${ }^{1}$, 4 Brandon Gray ${ }^{1}$, Liyong Cao ${ }^{1}$, Feng Chen $^{1}$, Huanzhi Shi ${ }^{1}$, Daniel E. Paniz-Perez ${ }^{3}$, Paul A. Paniz-Perez ${ }^{3}$, 5 Aryan L. Rishi ${ }^{3}$, Jacob Dubinsky ${ }^{3}$, Dylan Dubinsky $^{3}$, Owen Dubinsky ${ }^{3}$, Sophie Baine ${ }^{3}$, Lily Baine ${ }^{3}$,

6 Suzanne Arinsburg ${ }^{1}$, Ian Baine ${ }^{1}$, Juan David Ramirez ${ }^{1}$, Carlos Cordon-Cardo ${ }^{1}$, Emilia Mia Sordillo ${ }^{1}$, 7 Alberto E. Paniz-Mondolfi ${ }^{1, \#}$

9 Affiliations:

$10{ }^{1}$ Department of Pathology, Molecular, and Cell-Based Medicine, Icahn School of Medicine at Mount 11 Sinai, New York, NY 10029, USA

$12{ }^{2}$ Department of Medicine, Division of Infectious Diseases, Icahn School of Medicine at Mount Sinai, 13 New York, NY 10029, USA

$14{ }^{3}$ Department of Pathology, Molecular and Cell-Based Medicine, Kids Laboratory and Science Hub, 15 Icahn School of Medicine at Mount Sinai, New York, NY 10029, USA

17 \# Corresponding authors: matthew.hernandez@mssm.edu, alberto.paniz-mondolfi@mountsinai.org

18 Brief description: Saliva is a non-invasive, easy-to-collect specimen for virus detection in children.

19 However, children's diets introduce substances which interfere with diagnostics. Healthy children's 20 saliva collected immediately after eating various foods interfered with detection of artificially-added

21 SARS-CoV-2 nucleic acids. Diagnostic interference resolved at 20 minutes after eating.

22 Running head: Interference of SARS-CoV-2 detection in pediatric saliva

23 Keywords: RT-PCR; MALDI-TOF; Saliva; Interference; SARS-CoV-2 


\section{Abstract}

25 Background: Saliva is an optimal specimen for detection of viruses that cause upper respiratory

26 infections including severe acute respiratory syndrome coronavirus 2 (SARS-CoV-2) due to its cost-

27 effectiveness and non-invasive collection. However, together with intrinsic enzymes and oral

28 microbiota, children's unique dietary habits may introduce substances that interfere with diagnostic

29 testing.

30 Methods: To determine whether children's dietary choices impact SARS-CoV-2 detection in saliva, we

31 performed a diagnostic study that simulates testing of real-life specimens provided from healthy children

$32(\mathrm{n}=5)$ who self-collected saliva at home before and at 0, 20, and 60 minutes after eating from 20 foods

33 they selected. Each of seventy-two specimens was split into two volumes and spiked with SARS-CoV-

34 2-negative or -positive standards prior to side-by-side testing by reverse-transcription polymerase chain

35 reaction matrix-assisted laser desorption ionization time-of-flight (RT-PCR/MALDI-TOF) assay.

36 Results: Detection of internal extraction control and SARS-CoV-2 nucleic acids was reduced in

37 replicates of saliva collected at 0 minutes after eating 11 of 20 foods. Interference resolved at 20 and 60

38 minutes after eating all foods except hot dog in one participant. This represented a significant

39 improvement in detection of nucleic acids compared to saliva collected at 0 minutes after eating

$40 \quad(\mathrm{P}=0.0005)$.

41 Conclusions: We demonstrate successful detection of viral nucleic acids in saliva self-collected by

42 children before and after eating a variety of foods. Fasting is not required before saliva collection for

43 SARS-CoV-2 testing by RT-PCR/MALDI-TOF, but waiting 20 minutes after eating is sufficient for 44 accurate testing. These findings should be considered for SARS-CoV-2 testing and broader viral 45 diagnostics in saliva specimens. 
medRxiv preprint doi: https://doi.org/10.1101/2021.12.09.21267539; this version posted December 11, 2021. The copyright holder for this preprint (which was not certified by peer review) is the author/funder, who has granted medRxiv a license to display the preprint in perpetuity. It is made available under a CC-BY-ND 4.0 International license .

\section{Introduction}

Robust diagnostics are vital for testing of respiratory viral infections including severe acute respiratory syndrome coronavirus 2 (SARS-CoV-2) in order to prevent transmission from infected children. Although many nucleic acid amplification platforms for SARS-CoV-2 detection have been authorized by the United States Food and Drug Administration (US FDA) for testing nasopharyngeal (NP) specimens, collection involves invasive techniques and close-contact with infected individuals [1]. Saliva is an attractive alternative since collection is less invasive, uncomfortable, and saliva can be selfcollected.

We [2] and others [3-6] have demonstrated the diagnostic utility of saliva for SARS-CoV-2 testing, and several have demonstrated comparable sensitivities for SARS-CoV-2 detection in saliva versus NP specimens [5,7]; but few have assessed performance in children [4,5] whose saliva can be impacted by dietary and oral hygiene behaviors distinct from adults. With routine self-collection, robust detection of viruses are vulnerable to inhibitors found in saliva secondary to foods, dental care, or native salivary environment [8-10].

To evaluate whether dietary choices can impact SARS-CoV-2 detection in saliva, we performed a diagnostic study to simulate testing of real-life specimens provided from healthy children who selfcollected saliva at home before and after eating foods they selected. 


\section{Methods} \\ Ethics statement}

This study was reviewed and approved by the Institutional Review Board of the Icahn School of

67 Medicine at Mount Sinai (HS\#21-00670). Consent was obtained from at least one parent of each child 68 participant.

69 Foods evaluated for interference with target detection

A panel of 20 "favorite" foods was identified by the participants who also collaborated in the

71 study design. Detailed information on these foods are in the Supplemental Table 1. Participants'

72 renderings of select foods are depicted in Figure 1A and Supplemental Figures 1-4.

\section{Saliva collection}

Saliva specimens were provided by five healthy children aged between 5 and 9 years. Children self-collected specimens in sterile collection devices that have received emergency use authorization (EUA) by the US FDA for at-home saliva collection for SARS-CoV-2 testing. Participants provided

77 saliva once immediately upon waking up prior to any dental care, and then at 0,20 , and 60 minutes after eating each food. Parents annotated the food, timepoint, and date of specimen collection on each tube with a marker. Specimens were refrigerated in biohazard bags until transfer to the Mount Sinai Health

81 1988, 42 U.S.C. $\$ 263 a$ and meets requirements to perform high-complexity tests.

Upon receipt, specimen volumes were divided in half to undergo artificial spiking with in-house

84 standards prior to diagnostic testing using the Agena MassARRAY ${ }^{\circledR}$ SARS-CoV-2 Panel and

85 MassARRAY ${ }^{\circledR}$ System (Agena, CPM384) platform as previously described [2]. This method has been

86 validated for clinical testing and has received EUA by the US FDA. For each specimen collected, one 
medRxiv preprint doi: https://doi.org/10.1101/2021.12.09.21267539; this version posted December 11, 2021. The copyright holder for this preprint (which was not certified by peer review) is the author/funder, who has granted medRxiv a license to display the preprint in perpetuity. It is made available under a CC-BY-ND 4.0 International license .

87 volume was spiked with a quantitated standard of pooled SARS-CoV-2-positive NP specimens [2]. This

88 generated 1-3 technical replicates of saliva at 300uL each containing 125,000 copies/mL of SARS-CoV-

89 2. The second volume of saliva specimen was spiked with pooled SARS-CoV-2-negative NP matrix 90 standard which generated 1-3 replicates of saliva at 300uL each containing no SARS-CoV-2. Specimen 91 replicates were processed and run side-by-side.

92 Data acquired by the MassARRAY ${ }^{\circledR}$ Analyzer was processed with the MassARRAY ${ }^{\circledR}$ Typer and

93 SARS-CoV-2 Report software. The assay detects five viral targets: three in the $N$ gene (N1, N2, N3) and 94 two in the ORFlab gene (ORF1A, ORF1AB). If the internal extraction control (IC) was detected, results 95 were interpreted as positive if $\geq 2$ targets were detected or negative if $<2$ targets were detected. If no IC 96 and no targets were detected, the result was invalid. If IC was not detected but $\geq 2$ SARS-CoV-2 targets 97 were detected, the result was positive; notably, this outcome was not observed for any 98 specimens/replicates in this study. Detailed diagnostic results for all replicates are described in 99 Supplemental Table 2. Participants' depictions of methods are portrayed in Supplemental Figures 5-6. 100 Mass-spectrometry spectra representative of possible outcomes observed in this study are depicted in 101 Supplemental Figures 7-11.

102 Statistical analyses and display items

103 To compare detection frequency results at different timepoints of all saliva specimens tested, 104 normality was assessed by D’Agostino and Pearson test and Wilcoxon matched-pairs signed rank test 105 was performed (GraphPad Prism 9.0.2). 


\section{Results}

Pediatric participants independently selected 20 of their favorite foods and provided saliva for RT-PCR/MALDI-TOF detection of artificially-added viral and control nucleic acids (Figure 1). Altogether, 72 different saliva specimens were collected before and after eating. All specimens were divided into two volumes to undergo side-by-side testing after spiking with in-house SARS-CoV-2negative or -positive standards. In total, 404 replicates were tested.

We assessed the successful extraction and detection of internal extraction controls (IC) in specimens that were spiked with SARS-CoV-2-negative standard (Table 1). First, morning saliva collected immediately upon waking was collected from each participant. Morning saliva from four participants yielded successful detection of IC and a negative result for SARS-CoV-2 in $100 \%$ of replicates. In contrast, IC was detected in 0/3 replicates $(0 \%)$ of participant \#1 morning saliva suggesting the presence of substances that inhibit extraction or detection of IC. Morning saliva from a second independent collection for this participant yielded IC detection in $2 / 3$ replicates (67\%) highlighting consistent interference.

When we assessed interference in saliva collected after eating, we found the greatest interference with IC detection occurred in specimens collected immediately after eating ( 0 minutes) (Table 1). In saliva collected immediately after eating 12 foods, IC was detected in 0-67\% of replicates. However, for 11 of the 12 foods, IC was detected in $100 \%$ of replicates at 20 and 60 minutes after eating representing a significant improvement from the 0 minute timepoint $(\mathrm{P}=0.0005)$. Interestingly, saliva collected after eating hot dog were the exception and interfered with IC detection up to 60 minutes after consumption in participant \#1. Notably, participant \#3 also consumed hot dog, but IC was detected in all replicates from 0 to 60 minutes after eating. 

spiked samples. To do this, we spiked specimens with SARS-CoV-2-positive standard to generate replicates of specimens each containing 125,000 virus copies/mL, a concentration that is $\sim 100$-fold greater than the overall limit of detection for this saliva assay [2].

\#1 (Table 2). Together with the failure to detect IC in morning saliva from the same participant, these collection was spiked with SARS-CoV-2, viral nucleic acids were detected in 0/3 replicates (Supplemental Table 2).

Similar to saliva spiked with SARS-CoV-2-negative standard, the greatest interference with detection occurred in specimens collected immediately after eating (Table 2). Specifically, SARS-CoV1412 was detected in $0-50 \%$ of all replicates from SARS-CoV-2-spiked saliva collected immediately after 142 eating 11 foods. These same foods were all associated with inhibition of detection of IC nucleic acids in 143 paired specimens spiked with SARS-CoV-2-negative standard. Interestingly, for participant \#3, contrary 144 to detection of IC in SARS-CoV-2-negative saliva collected immediately after eating hot dog, viral 145 nucleic acids were detected in $0 / 3$ replicates $(0 \%)$ of paired saliva spiked with SARS-CoV-2. Successful 146 detection of SARS-CoV-2 was achieved in saliva collected at 20 to 60 minutes after eating almost all 147 (19/20) foods which represents a significant improvement in detection compared to the 0 minute 148 timepoint $(\mathrm{P}=0.0010)$. Once again, the exception was for participant \#1 saliva collected after eating hot 149 dog which interfered with SARS-CoV-2 detection up to one hour later. 


\section{Discussion}

As children return to in-person schooling, large-scale SARS-CoV-2 screening and surveillance

152 efforts have utilized saliva for its cost-effective, non-invasive, and safe characteristics in testing children 153 and adults [11]. However, to effectively execute these initiatives and to exploit saliva for testing of other 154 viruses, a better assessment of diagnostic performance of saliva in children is required. In particular, the 155 requirement to fast or avoid eating may be difficult for parents and children because of constraints on mealtime scheduling and unpredictability of children's dietary habits.

To address this, the children who participated in our study collected saliva upon waking, and then, at set intervals, after eating their favorite foods. Although the number of participants in this study

162 further study on other RT-PCR-based and novel (e.g., RT loop-mediated isothermal amplification, 163 CRISPR/Cas-based) diagnostic platforms. 
medRxiv preprint doi: https://doi.org/10.1101/2021.12.09.21267539; this version posted December 11, 2021. The copyright holder for this preprint (which was not certified by peer review) is the author/funder, who has granted medRxiv a license to display the preprint in perpetuity. It is made available under a CC-BY-ND 4.0 International license.

\section{Acknowledgments}

172 We would like to thank all of the children and their parents for their participation in this study 173 and for ultimately advancing the viral diagnostics. We are also grateful for the continuous expert 174 guidance provided by the ISMMS Program for the Protection of Human Subjects.

175

\section{Financial support}

177

The authors received no financial support for the research, authorship, or publication of this 178 article.

179

180 Potential conflicts of interest

181 The authors have no reported conflicts of interest to disclose for this study. 


\section{References}

[1] O. Vandenberg, D. Martiny, O. Rochas, A. van Belkum, Z. Kozlakidis, Considerations for diagnostic COVID-19 tests, Nat. Rev. Microbiol. 19 (2021) 171-183.

[2] M.M. Hernandez, R. Banu, P. Shrestha, A. Patel, F. Chen, L. Cao, S. Fabre, J. Tan, H. Lopez, N. Chiu, B. Shifrin, I. Zapolskaya, V. Flores, P.Y. Lee, S. Castañeda, J.D. Ramírez, J. Jhang, G. Osorio, M.R. Gitman, M.D. Nowak, D.L. Reich, C. Cordon-Cardo, E.M. Sordillo, A.E. PanizMondolfi, RT-PCR/MALDI-TOF mass spectrometry-based detection of SARS-CoV-2 in saliva specimens, J. Med. Virol. (2021). https://doi.org/10.1002/jmv.27069.

[3] A.L. Wyllie, J. Fournier, A. Casanovas-Massana, M. Campbell, M. Tokuyama, P. Vijayakumar, J.L. Warren, B. Geng, M.C. Muenker, A.J. Moore, C.B.F. Vogels, M.E. Petrone, I.M. Ott, P. Lu, A. Venkataraman, A. Lu-Culligan, J. Klein, R. Earnest, M. Simonov, R. Datta, R. Handoko, N. Naushad, L.R. Sewanan, J. Valdez, E.B. White, S. Lapidus, C.C. Kalinich, X. Jiang, D.J. Kim, E. Kudo, M. Linehan, T. Mao, M. Moriyama, J.E. Oh, A. Park, J. Silva, E. Song, T. Takahashi, M. Taura, O.-E. Weizman, P. Wong, Y. Yang, S. Bermejo, C.D. Odio, S.B. Omer, C.S. Dela Cruz, S. Farhadian, R.A. Martinello, A. Iwasaki, N.D. Grubaugh, A.I. Ko, Saliva or Nasopharyngeal Swab Specimens for Detection of SARS-CoV-2, N. Engl. J. Med. 383 (2020) 1283-1286.

[4] R. Yee, T.T. Truong, P.S. Pannaraj, N. Eubanks, E. Gai, J. Jumarang, L. Turner, A. Peralta, Y. Lee, J. Dien Bard, Saliva Is a Promising Alternative Specimen for the Detection of SARS-CoV-2 in Children and Adults, J. Clin. Microbiol. 59 (2021). https://doi.org/10.1128/JCM.02686-20.

[5] G. Butler-Laporte, A. Lawandi, I. Schiller, M.C. Yao, N. Dendukuri, E.G. McDonald, T.C. Lee, Comparison of Saliva and Nasopharyngeal Swab Nucleic Acid Amplification Testing for Detection of SARS-CoV-2: A Systematic Review and Meta-analysis, JAMA Intern. Med. (2021). https://doi.org/10.1001/jamainternmed.2020.8876.

[6] D. Banerjee, A. Sasidharan, A. Abdulhamid, E.M. Orosco, J.L. Watts, J.E. Schuster, A.L. Myers, G. Weddle, R. Selvarangan, Diagnostic Yield of Saliva for SARS-CoV-2 Molecular Testing in Children, J Pediatric Infect Dis Soc. (2021). https://doi.org/10.1093/jpids/piab058.

[7] R.A. Lee, J.C. Herigon, A. Benedetti, N.R. Pollock, C.M. Denkinger, Performance of Saliva, Oropharyngeal Swabs, and Nasal Swabs for SARS-CoV-2 Molecular Detection: A Systematic Review and Meta-analysis, J. Clin. Microbiol. (2021). https://doi.org/10.1128/JCM.02881-20.

[8] C. Schrader, A. Schielke, L. Ellerbroek, R. Johne, PCR inhibitors - occurrence, properties and removal, J. Appl. Microbiol. 113 (2012) 1014-1026.

[9] C. Suther, M.D. Moore, Quantification and discovery of PCR inhibitors found in food matrices commonly associated with foodborne viruses, Food Science and Human Wellness. 8 (2019) 351355.

[10] L. Rossen, P. Nørskov, K. Holmstrøm, O.F. Rasmussen, Inhibition of PCR by components of food samples, microbial diagnostic assays and DNA-extraction solutions, Int. J. Food Microbiol. 17 (1992) 37-45.

[11] J. Crowe, A.T. Schnaubelt, S. SchmidtBonne, K. Angell, J. Bai, T. Eske, M. Nicklin, C. Pratt, B. White, B. Crotts-Hannibal, N. Staffend, V. Herrera, J. Cobb, J. Conner, J. Carstens, J. Tempero, L. Bouda, M. Ray, J.V. Lawler, W.S. Campbell, J.-M. Lowe, J. Santarpia, S. Bartelt-Hunt, M. Wiley, D. Brett-Major, C. Logan, M.J. Broadhurst, Assessment of a Program for SARS-CoV-2 Screening and Environmental Monitoring in an Urban Public School District, JAMA Netw Open. 4 (2021) e2126447.

[12] S.P. Humphrey, R.T. Williamson, A review of saliva: normal composition, flow, and function, J. Prosthet. Dent. 85 (2001) 162-169. 
medRxiv preprint doi: https://doi.org/10.1101/2021.12.09.21267539; this version posted December 11, 2021. The copyright holder for this preprint (which was not certified by peer review) is the author/funder, who has granted medRxiv a license to display the preprint in perpetuity. It is made available under a CC-BY-ND 4.0 International license .

\section{Author contributions}

228 M.C.B. and M.RC. recruited and consented parents and subjects to provide specimens for this study.

229 D.E.P.P, P.A.P.P, A.L.R, J.D, D.D, S.B, and L.B participated in the design and implementation of the 230 research. M.M.H., R.B., P.S., L.C., F.C., and A.E.PM. accessioned subjects' specimens and performed 231 diagnostic assays. M.M.H., R.B., H.S., E.M.S., and A.E.PM analyzed, interpreted, or discussed data. 232 S.A., I.B., M.R.G., M.D.N., and C.C.C contributed to the interpretation of the results. M.M.H., E.M.S., 233 and A.E.PM. wrote the manuscript. M.M.H. and A.E.PM. conceived the study. E.M.S. and A.E.PM. 234 supervised the study. All authors discussed the results and commented on the manuscript.

235 M.M.H. and A.E.PM are the guarantors of this work and, as such, had full access to all of the data in the 236 study and take responsibility for the integrity of the data and the accuracy of the data analysis. 
medRxiv preprint doi: https://doi.org/10.1101/2021.12.09.21267539; this version posted December 11, 2021. The copyright holder for this preprint (which was not certified by peer review) is the author/funder, who has granted medRxiv a license to display the preprint in perpetuity. It is made available under a CC-BY-ND 4.0 International license .

\section{Figure and Table Legends}

241 Figure 1. Foods selected by participants to test for interference of SARS-CoV-2 diagnostic testing

242 in saliva. (A) Participants' rendering of select categories of foods tested for impact on SARS-CoV-2

243 detection in saliva. (B) Participants' rendition of process of collecting saliva, artificially spiking with (or 244 without) SARS-CoV-2, RNA extraction, and RT-PCR/MALDI-TOF diagnostic testing.

246 Table 1. Detection of extraction control in children's saliva before and after eating. 
Figure 1

A
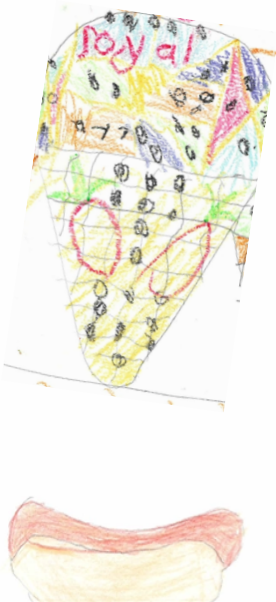

$1100 \mathrm{dag}$
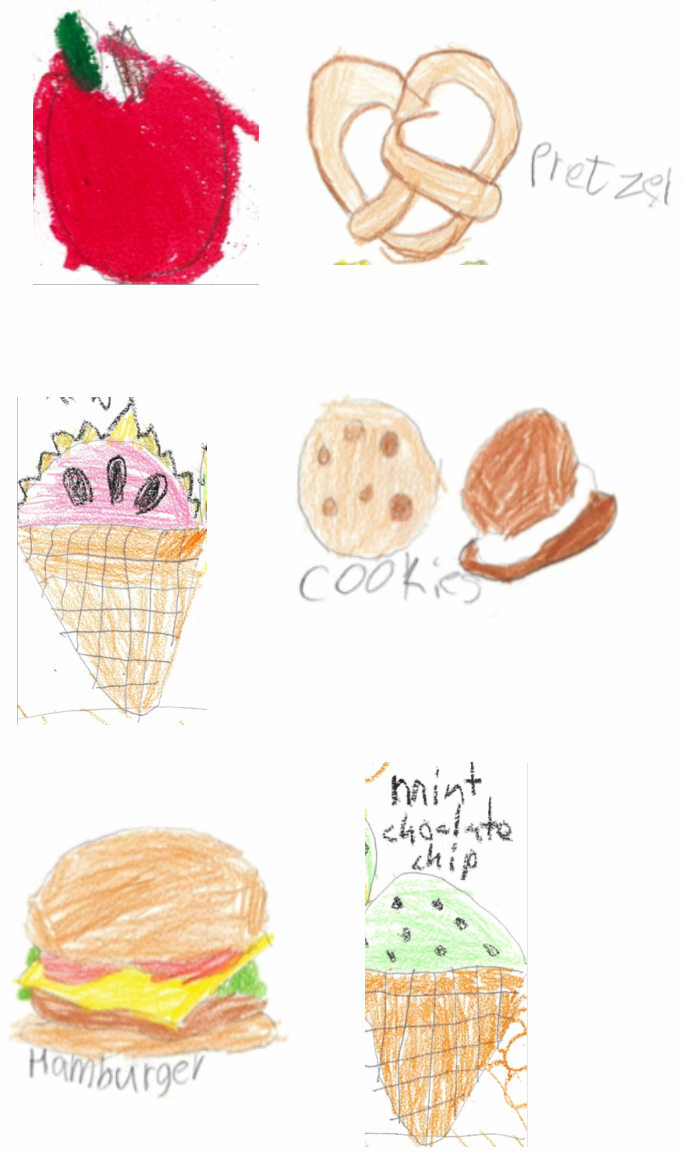

B
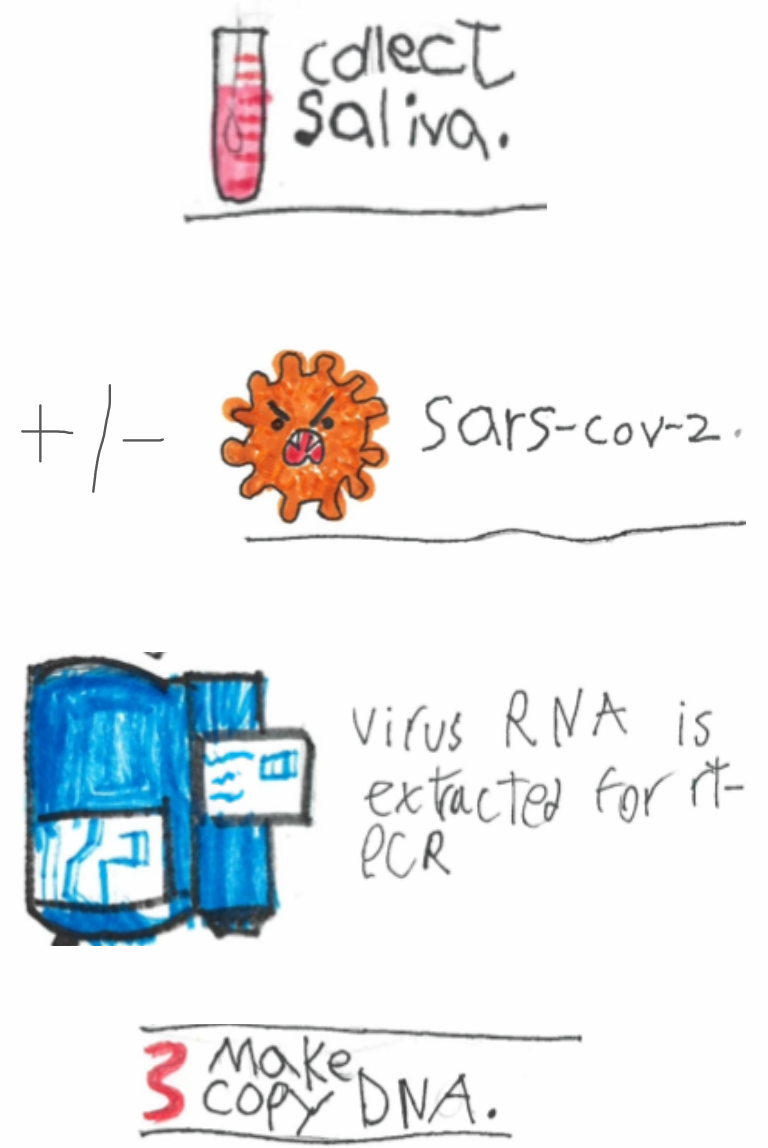

\& make manis

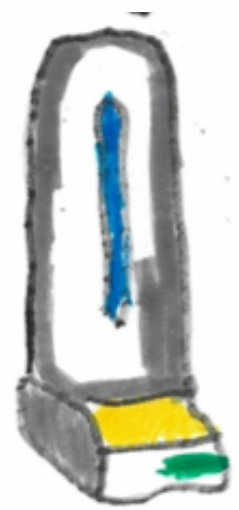

andread on Agena massurray.

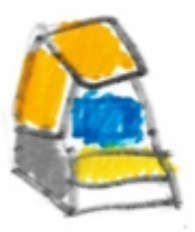


medRxiv preprint doi: https://doi.org/10.1101/2021.12.09.21267539; this version posted December 11, 2021. The copyright holder for this preprint (which was not certified by peer review) is the author/funder, who has granted medRxiv a license to display the preprint in perpetuity.

It is made available under a CC-BY-ND 4.0 International license .

Table 1. Detection of internal extraction control in children's saliva before and after eating.

\begin{tabular}{|c|c|c|c|c|c|}
\hline \multirow[b]{2}{*}{ Participant } & \multirow[b]{2}{*}{ Morning $^{\mathbf{b}}$} & \multicolumn{4}{|c|}{ After eating $^{a}$} \\
\hline & & Food & 0 minutes & 20 minutes & 60 minutes \\
\hline \multirow{6}{*}{1} & $0 / 3(0 \%)$ & --- & --- & --- & --- \\
\hline & --- & Hot Dog & $0 / 3(0 \%)$ & $2 / 3(66.7 \%)$ & $2 / 3(66.7 \%)$ \\
\hline & --- & Ice Cream & $0 / 3(0 \%)$ & $3 / 3(100 \%)$ & $3 / 3(100 \%)$ \\
\hline & --- & Cookies & $0 / 3(0 \%)$ & $3 / 3(100 \%)$ & $3 / 3(100 \%)$ \\
\hline & --- & Pizza & $0 / 2(0 \%)$ & $3 / 3(100 \%)$ & $3 / 3(100 \%)$ \\
\hline & --- & Pretzels & $0 / 3(0 \%)$ & $3 / 3(100 \%)$ & $3 / 3(100 \%)$ \\
\hline \multirow{10}{*}{2} & $3 / 3(100 \%)$ & --- & --- & --- & --- \\
\hline & --- & Apple & $2 / 2(100 \%)$ & $2 / 2(100 \%)$ & $3 / 3(100 \%)$ \\
\hline & --- & Banana & $0 / 3(0 \%)$ & $3 / 3(100 \%)$ & $3 / 3(100 \%)$ \\
\hline & --- & Chocolate & $2 / 3(66.7 \%)$ & $3 / 3(100 \%)$ & $3 / 3(100 \%)$ \\
\hline & --- & Clementine & $3 / 3(100 \%)$ & $3 / 3(100 \%)$ & $3 / 3(100 \%)$ \\
\hline & --- & Hamburger & $3 / 3(100 \%)$ & $2 / 2(100 \%)$ & $2 / 2(100 \%)$ \\
\hline & --- & Chicken Nuggets & $0 / 2(0 \%)$ & $3 / 3(100 \%)$ & $3 / 3(100 \%)$ \\
\hline & --- & Pasta & $1 / 2(50.0 \%)$ & $3 / 3(100 \%)$ & $3 / 3(100 \%)$ \\
\hline & --- & Popcorn & $2 / 2(100 \%)$ & $3 / 3(100 \%)$ & $2 / 2(100 \%)$ \\
\hline & --- & Waffle & $0 / 3(0 \%)$ & $3 / 3(100 \%)$ & $2 / 2(100 \%)$ \\
\hline \multirow{6}{*}{3} & $3 / 3(100 \%)$ & --- & --- & --- & --- \\
\hline & --- & Eggs \& Bacon & $3 / 3(100 \%)$ & $3 / 3(100 \%)$ & $3 / 3(100 \%)$ \\
\hline & --- & Macaroni \& Cheese & $3 / 3(100 \%)$ & $3 / 3(100 \%)$ & $3 / 3(100 \%)$ \\
\hline & --- & Peanut Butter \& Jelly & $3 / 3(100 \%)$ & $3 / 3(100 \%)$ & $3 / 3(100 \%)$ \\
\hline & --- & Potato Chips & $0 / 3(0 \%)$ & $3 / 3(100 \%)$ & $3 / 3(100 \%)$ \\
\hline & --- & Hot Dog & $3 / 3(100 \%)$ & $3 / 3(100 \%)$ & $3 / 3(100 \%)$ \\
\hline \multirow{3}{*}{4} & $1 / 1(100 \%)$ & --- & --- & --- & --- \\
\hline & --- & French Fries & $0 / 3(0 \%)$ & $3 / 3(100 \%)$ & $3 / 3(100 \%)$ \\
\hline & --- & Pancake & $3 / 3(100 \%)$ & $3 / 3(100 \%)$ & $3 / 3(100 \%)$ \\
\hline \multirow{2}{*}{5} & $3 / 3(100 \%)$ & --- & --- & --- & --- \\
\hline & --- & French Fries & $2 / 2(100 \%)$ & $2 / 2(100 \%)$ & $3 / 3(100 \%)$ \\
\hline Overall & $10 / 13(76.9 \%)$ & --- & $30 / 60(50.0 \%)$ & $62 / 63(98.4 \%)$ & $62 / 63(98.4 \%)$ \\
\hline
\end{tabular}

a Fraction of saliva replicates collected after eating that are spiked with SARS-CoV-2-negative NP matrix and yield detectable internal extraction control. Fraction also depicted as percentage.

b Fraction of saliva replicates collected in the morning that are spiked with SARS-CoV-2-negative NP matrix and yield detectable internal extraction control. Fraction also depicted as percentage. 
medRxiv preprint doi: https://doi.org/10.1101/2021.12.09.21267539; this version posted December 11, 2021. The copyright holder for this preprint (which was not certified by peer review) is the author/funder, who has granted medRxiv a license to display the preprint in perpetuity.

It is made available under a CC-BY-ND 4.0 International license .

Table 2. Detection of SARS-CoV-2 in children's saliva before and after eating

\begin{tabular}{|c|c|c|c|c|c|}
\hline \multirow[b]{2}{*}{ Participant } & \multirow[b]{2}{*}{ Morning $^{\mathbf{b}}$} & \multicolumn{4}{|c|}{ After eating $^{a}$} \\
\hline & & Food & 0 minutes & 20 minutes & 60 minutes \\
\hline \multirow{6}{*}{1} & $0 / 3(0 \%)$ & --- & --- & --- & --- \\
\hline & --- & Hot Dog & $0 / 3(0 \%)$ & $2 / 3(66.7 \%)$ & $2 / 3(66.7 \%)$ \\
\hline & --- & Ice Cream & $0 / 3(0 \%)$ & $3 / 3(100 \%)$ & $3 / 3(100 \%)$ \\
\hline & --- & Cookies & $1 / 3(33.3 \%)$ & $3 / 3(100 \%)$ & $3 / 3(100 \%)$ \\
\hline & --- & Pizza & $1 / 2(50.0 \%)$ & $3 / 3(100 \%)$ & $3 / 3(100 \%)$ \\
\hline & --- & Pretzels & $0 / 3(0 \%)$ & $3 / 3(100 \%)$ & $3 / 3(100 \%)$ \\
\hline \multirow{10}{*}{2} & $3 / 3(100 \%)$ & --- & --- & --- & --- \\
\hline & --- & Apple & $2 / 2(100 \%)$ & $2 / 2(100 \%)$ & $3 / 3(100 \%)$ \\
\hline & --- & Banana & $1 / 3(33.3 \%)$ & $3 / 3(100 \%)$ & $3 / 3(100 \%)$ \\
\hline & --- & Chocolate & $3 / 3(100 \%)$ & $3 / 3(100 \%)$ & $3 / 3(100 \%)$ \\
\hline & --- & Clementine & $3 / 3(100 \%)$ & $3 / 3(100 \%)$ & $3 / 3(100 \%)$ \\
\hline & --- & Hamburger & $3 / 3(100 \%)$ & $2 / 2(100 \%)$ & $2 / 2(100 \%)$ \\
\hline & --- & Chicken Nuggets & $1 / 2(50.0 \%)$ & $3 / 3(100 \%)$ & $3 / 3(100 \%)$ \\
\hline & --- & Pasta & $1 / 2(50.0 \%)$ & $3 / 3(100 \%)$ & $3 / 3(100 \%)$ \\
\hline & --- & Popcorn & $2 / 2(100 \%)$ & $3 / 3(100 \%)$ & $2 / 2(100 \%)$ \\
\hline & --- & Waffle & $0 / 3(0 \%)$ & $3 / 3(100 \%)$ & $2 / 2(100 \%)$ \\
\hline \multirow{6}{*}{3} & $3 / 3(100 \%)$ & --- & --- & --- & --- \\
\hline & --- & Eggs \& Bacon & $3 / 3(100 \%)$ & $3 / 3(100 \%)$ & $3 / 3(100 \%)$ \\
\hline & --- & Macaroni \& Cheese & $3 / 3(100 \%)$ & $3 / 3(100 \%)$ & $3 / 3(100 \%)$ \\
\hline & --- & Peanut Butter \& Jelly & $3 / 3(100 \%)$ & $3 / 3(100 \%)$ & $3 / 3(100 \%)$ \\
\hline & --- & Potato Chips & $0 / 3(0 \%)$ & $3 / 3(100 \%)$ & $3 / 3(100 \%)$ \\
\hline & --- & Hot Dog & $0 / 3(0 \%)$ & $3 / 3(100 \%)$ & $3 / 3(100 \%)$ \\
\hline \multirow{3}{*}{4} & $1 / 1(100 \%)$ & --- & --- & --- & --- \\
\hline & --- & French Fries & $0 / 3(0 \%)$ & $3 / 3(100 \%)$ & $3 / 3(100 \%)$ \\
\hline & --- & Pancake & $3 / 3(100 \%)$ & $3 / 3(100 \%)$ & $3 / 3(100 \%)$ \\
\hline \multirow{2}{*}{5} & $3 / 3(100 \%)$ & --- & --- & --- & --- \\
\hline & --- & French Fries & $2 / 2(100 \%)$ & $2 / 2(100 \%)$ & $3 / 3(100 \%)$ \\
\hline Overall & $10 / 13(76.9 \%)$ & --- & $32 / 60(53.3 \%)$ & $62 / 63(98.4 \%)$ & $62 / 63(98.4 \%)$ \\
\hline
\end{tabular}

a Fraction of saliva replicates collected after eating that are spiked with SARS-CoV-2-positive NP matrix and yield detectable SARS-CoV-2. Fraction also depicted as percentage.

b Fraction of saliva replicates collected in the morning that are spiked with SARS-CoV-2-positive NP matrix and yield detectable SARS-CoV-2. Fraction also depicted as percentage. 